\title{
Proposal of Ecotechnologies for Tilapia (Oreochromis niloticus) Production in Mexico: Economic, Environmental, and Social Implications
}

\author{
Erick Arturo Betanzo-Torres ${ }^{1}{ }^{(D)}$, María de los Ángeles Piñar-Álvarez ${ }^{2}$ (D) Celia Gabriela Sierra-Carmona ${ }^{3}{ }^{(D)}$, \\ Luis Enrique García Santamaria ${ }^{1}{ }^{(D}$, Cecilia-Irene Loeza-Mejía ${ }^{1}\left(\mathbb{D}\right.$, José Luis Marín-Muñiz ${ }^{2, * D}$ \\ and Luis Carlos Sandoval Herazo ${ }^{1, * \mathbb{D}}$
}

1 Division of Postgraduate Studies and Research, Tecnológico Nacional de México, Instituto Tecnológico Superior de Misantla, Misantla 93821, Mexico; eabetanzot@itsm.edu.mx (E.A.B.-T.); legarcias@itsm.edu.mx (L.E.G.S.); cecilialoeza@yahoo.com (C.-I.L.-M.)

2 Scientific Research Department, El Colegio de Veracruz, Xalapa 91000, Mexico; angelespinaralvarez@gmail.com

3 Division of Postgraduate Studies and Research, Tecnológico Nacional de México, Instituto Tecnológico Superior de Xalapa, Xalapa 91096, Mexico; celiagaby85@gmail.com

* Correspondence: soydrew@hotmail.com (J.L.M.-M.); lcsandovalh@gmail.com (L.C.S.H.)

Citation: Betanzo-Torres, E.A.;

Piñar-Álvarez, M.d.l.Á.;

Sierra-Carmona, C.G.; Santamaria,

L.E.G.; Loeza-Mejía, C.-I.;

Marín-Muñiz, J.L.; Sandoval Herazo,

L.C. Proposal of Ecotechnologies for

Tilapia (Oreochromis niloticus)

Production in Mexico: Economic,

Environmental, and Social

Implications. Sustainability 2021, 13,

6853. https://doi.org/10.3390/

su13126853

Academic Editor:

Malgorzata Jasiulewicz-Kaczmarek

Received: 5 May 2021

Accepted: 11 June 2021

Published: 17 June 2021

Publisher's Note: MDPI stays neutral with regard to jurisdictional claims in published maps and institutional affiliations.

Copyright: (c) 2021 by the authors. Licensee MDPI, Basel, Switzerland. This article is an open access article distributed under the terms and conditions of the Creative Commons Attribution (CC BY) license (https:// creativecommons.org/licenses/by/ $4.0 /)$.

\begin{abstract}
Conventional aquaculture (ACUA-C) in Mexico is an activity that maintains an annual growth rate of $6 \%$. Tilapia (Oreochromis niloticus) aquaculture is the predominant aquaculture in the country with 4623 farms, most of which operate with semi-intensive (SIS) and extensive (ES) production systems, discharging untreated wastewater that negatively impacts the environment. To address this problem, new ecotechnologies such as biofloc (BFT), recirculation systems for aquaculture (RAS), constructed wetlands (CWs) for water treatment, and aquaponics (AS) have emerged to mitigate the environmental impacts of untreated wastewater. The objective of this work is to evaluate the feasibility of tilapia farming with BFT, RAS, CW, and AS ecotechnologies through an economic and financial feasibility analysis, considering their environmental and social implications in a Mexican aquaculture farm located in the state of Veracruz. Open interviews, direct observation, and diagnosis of the semi-intensive tilapia system was carried out between 15 May 2019 and 15 February 2020 in order to calculate, design, and theoretically evaluate the four ecotechnological alternatives (TBF, RAS, CW, and AS). Economic (13), environmental (10), and social (5) variables were applied, making use of the same facilities. The results reveal that the four ecotechnologies implemented in an SIS are economically viable and environmentally acceptable, especially in water management, in addition to being socially feasible. It is concluded that BFT offers an alternative to the producer by having a lower additional cost to improve problems, despite the possible complexity of operation and energy requirements to manage wastewater treatment. The technological transition to BFT is recommended to solve the problem of sustainable water management.
\end{abstract}

Keywords: sustainable aquaculture; recirculation aquaculture systems; biofloc technology; constructed wetlands; aquaponics

\section{Introduction}

The productive activity with the highest growth in the agricultural sector in recent decades has been aquaculture [1], presenting an annual growth of $5.8 \%$ during the period from 2000 to 2018 [2], which is faster than other animal production segments [3]. Among the species of relevance in aquaculture are cichlids (tilapia), representing the largest aquaculture production group in the world [4]. Tilapia is the common name given to three genera of the family Cichlidae: Oreochromis, Sarotherodon, and Tilapia [5]. The most important species for aquaculture are in the genus Oreochromis and are O. mossambicus, O. 
aureus, and O. niloticus. The latter is the most cultivated [6] representing $80 \%$ of tilapia cultivated worldwide [7]. Mexico is no exception, where aquaculture maintains a growth rate higher than the world rate (36\%) over a period of 6 years, $6 \%$ annually, as pointed out by SAGARPA [8], CONAPESCA [9], and Reyes-Vera et al. [10].

The number of aquaculture farms is close to 9300 APUs (aquaculture production units). Among these, tilapia aquaculture is predominant in the country with 4623 official farms in operation [8]. However, this production still does not meet the needs and per capita consumption; therefore, tilapia is imported. Open systems with low productivity are the prevailing ones; among the most used systems are earthen ponds, concrete, geomembranes, both rectangular and circular, and in some regions where permitted, floating cages on reservoirs and rivers [8,11-15]. The operation of these aquaculture systems has an impact on the environment due to wastewater discharges from aquaculture farms, which contain a high amount of pollutants [16,17]. Consequently, water management in aquaculture systems needs to be more efficient.

Furthermore, food security in terms of aquaculture plays a relevant role due to global population growth, which exceeds 7.2 billion and continues to grow [18]. Expectations indicate that by 2050 the human population will be more than 9 billion people; therefore, current production systems that are highly extractive of natural resources (land and water) have to change [19]. Currently, ecotechnologies for production can be implemented in aquaculture production systems and these, when available, can recycle water and/or combine it with aqua-agricultural systems. As noted by Barrington et al. [20], Béné et al. [21], and FAO [2], ecotechnologies are a growing need in aquaculture systems. These systems include biofloc technology [22,23], recirculation systems in aquaculture [24], constructed wetlands for the treatment of discharge influents in aquaculture [25,26], aquaponics systems [27], and recently, aquamimicry technology $[28,29]$.

\section{Sustainable Aquaculture and Ecotechnologies for Production}

Most current aquaculture production systems seek to be intensive [30] due to the need to increase global food production from $25 \%$ to $70 \%$ [31], so it is necessary for these to be sustainable and undergo technological change [32-34]. However, it should be taken into consideration that these systems, being mostly productive, should mainly mitigate the excessive consumption of water resources and be ecologically friendly by being less harmful to the environment. With regard to systems that reduce wastewater in aquaculture production, the following are analyzed in this work:

Biofloc technology (BFT): biotechnology that takes advantage of the accelerated growth of bacteria and microorganisms that consume suspended solids in water, eliminating nutrients that are not appropriate for cultivation, such as total nitrogen, nitrates, nitrites, and ammonium. In addition, they are a source of food for the culture organisms, being an in situ treatment system with minimal water replacement [22,35-40].

Aquaponics systems (AS): technologies that function as filters for all aquaculture system wastes and generate by-products (plants) of additional commercial value, which are responsible for absorbing nutrients from pond wastes [27,41-44].

Constructed wetlands for discharge treatment $(\mathrm{CW})$ : designed to remove as many nutrients as possible from contaminated municipal and industrial waters, such as from aquaculture ponds that are discharged to $\mathrm{CW}$ for biological purification, usually with phytoremediation plants, to be reused in the aquaculture system or discharged without adverse environmental effects, or used for agricultural irrigation [45-49]. It should be noted that, for the specific case of aquaculture waters, water contamination by ammonium is the most important compound to eliminate. If the latter is found in average concentrations greater than $1 \mathrm{mg} / \mathrm{L}$ it is harmful to organisms. Studies in wetlands have shown effective elimination of this pollutant with removals of $30 \%$ to $80 \%[50,51]$ even with concentrations of the nutrient higher than $5 \mathrm{mg} / \mathrm{L}$, which is used by plants for its bioabsorption, or also used during the nitrification process. 
Finally, recirculating aquaculture systems (RAS): nitrifying bacteria are used to convert ammonia nitrogen into nitrate allowing a high culture density, also reusing water in the same system, through equipment (settling, biological filtration, mechanical, aeration, pumping, and disinfection) that treat the water to reincorporate it into the aquaculture system $[24,52,53]$.

These systems have several characteristics in common: they seek to minimize water use and treat wastewater, basing their treatment on biotechnological principles for production, while trying to be economically viable with the purpose of increasing production, as well as avoiding environmental impacts due to eutrophication; they are considered closed aquaculture systems. These systems have their advantages and disadvantages and can be used individually or combined in hybrid recirculation systems [54]. However, they require different investments in assets and management, so the decision to implement them will depend on the particular conditions of the crop and the region where a farm with these systems is intended to be built.

These systems can be considered ecotechnologies, as proposed by Moreno et al. [55] who state that in developed countries a large part of the discussion on ecotechnologies has emphasized their use as a means to reduce environmental impacts, following the guidelines of sustainable technological development. Moreno et al. [55] (p. 16) proposed the following operational definition of the term ecotechnology: "Devices, methods and processes that promote a harmonious relationship with the environment and seek to provide tangible social and economic benefits to their users, with reference to a specific socio-ecological context".

For this reason, current aquaculture production systems, which can be defined as traditional aquaculture, are those that have a negative ecological impact in the excessive use of water and energy in their production process. The alternatives mentioned above are ecotechnologies because their development and application are part of the sustainable future of production systems.

It is essential to analyze the ecotechnologies under an integral perspective oriented to the sustainability of these systems and the context of the users. Therefore, the objective of this work is to evaluate the feasibility of tilapia (Oreochromis niloticus) culture with BFT, RAS, CW, and AS technologies, through an economic and financial feasibility analysis considering their environmental and social implications for the case study of a Mexican aquaculture farm.

\section{Methodology}

\subsection{Description of the Study Site}

The aquaculture farm used for this study is located in the community of Tierra Adentro, belonging to the Congregación de Joachín, municipality of Tierra Blanca, Veracruz (Figure 1). The farm is located between the coordinates $18^{\circ} 39^{\prime} 26^{\prime \prime}$ north latitude and $96^{\circ} 17^{\prime} 58^{\prime \prime}$ west longitude, at an altitude of $63 \mathrm{~m}$, having an approximate area of influence of 1000 hectares within the parallels $18^{\circ} 38^{\prime} 53^{\prime \prime} \mathrm{N}$ and $18^{\circ} 39^{\prime} 51^{\prime \prime} \mathrm{N}$ and meridians $96^{\circ} 18^{\prime} 18.54^{\prime \prime}$ $\mathrm{W} 96^{\circ} 16^{\prime} 43.34^{\prime \prime} \mathrm{W}$ within the UTM 14 zone, at an altitude of $63 \mathrm{~m}$. It is located in the climatic zone type Aw" 2 (w) (e) g, warm sub-humid, with an average temperature of $27.4^{\circ} \mathrm{C}$. Rainfall in the area reaches an average annual volume of $1573 \mathrm{~mm}$, concentrating more in the middle of the year [56]. 


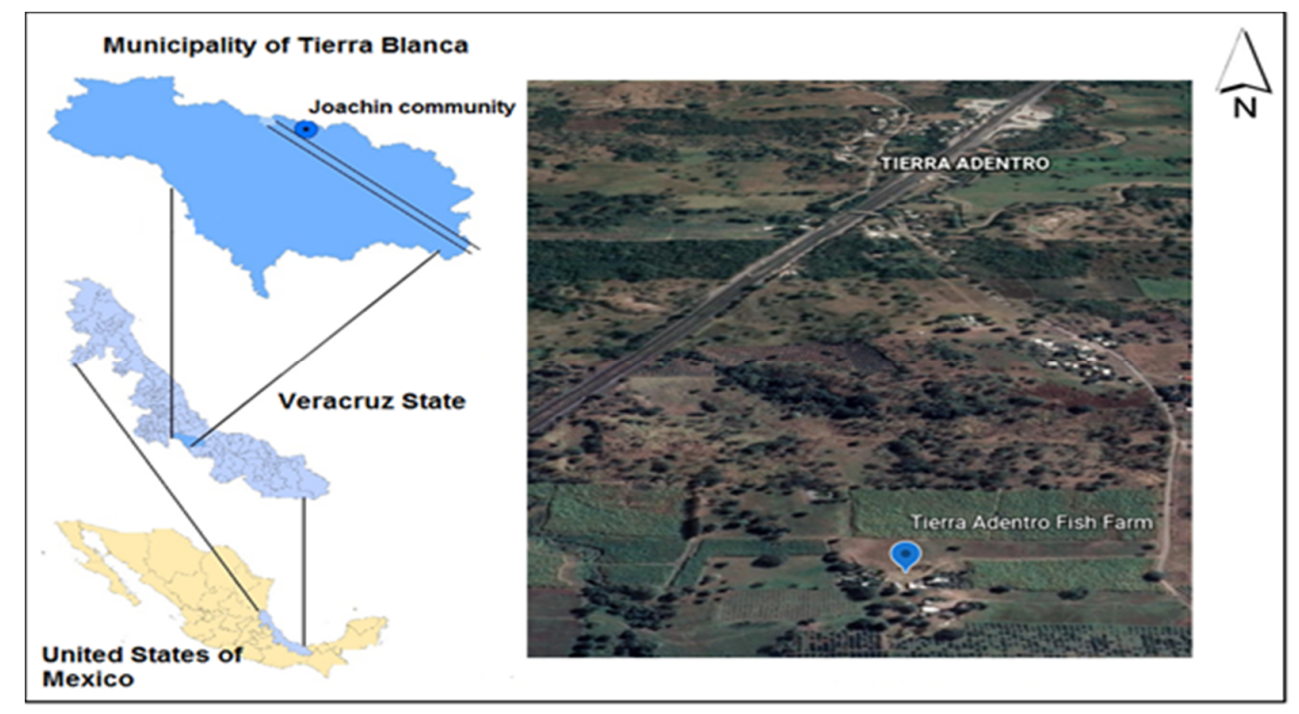

Figure 1. Location of the APU Tierra Adentro fish farm.

\subsection{Description of the Current Facility Analyzed}

The APU is divided into the pre-fattening and tilapia fattening modules. Module II, for tilapia fattening, covers an area of $600 \mathrm{~m}^{2}(0.06 \mathrm{ha})$ composed of 6 geomembrane ponds with a diameter of $12 \mathrm{~m}$ by $1.20 \mathrm{~m}$ high each, which served as the basis to contrast and propose alternative ecotechnologies for future implementation (Figure 2).

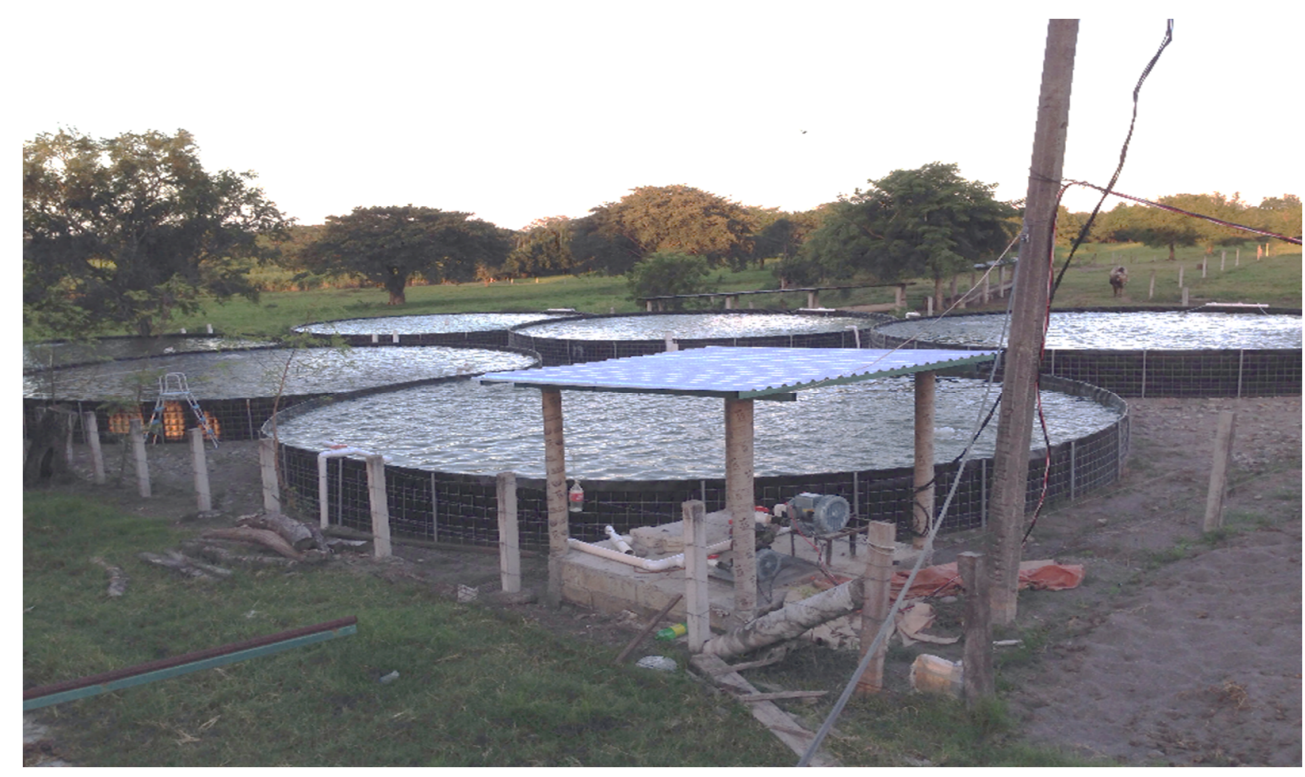

Figure 2. Tierra Adentro fish farm, current aquaculture facility, module II.

\subsection{Criteria for the Design of Alternative Ecotechnological Systems}

The designs of the proposed alternative ecotechnologies aimed to raise the income of the APU, to move from a REU (rural economic unit of stratum 4) (entrepreneurial with fragile profitability) to one of stratum 5 (thriving entrepreneurial) according to the classification of FAO-SAGARPA [57], while also mitigating the negative environmental impacts on water.

In terms of location and region, all calculations and estimates are adaptable to the tropics and the southeast region of Mexico, where the climatic characteristics are suitable for tilapia production $[24,58]$. 
Regarding the existing infrastructure, and in order to have a uniform criterion, it was determined that with the module used, it is technically feasible to compare it with the use of the four ecotechnologies for the consideration of Mexican producers.

\subsection{Data Collection from the Rural Aquaculture System, Semi-Intensive (SIS)}

The rural aquaculture semi-intensive system is currently in operation in module II (Figure 2). Data collection of the system operation is semi-intensive and the analysis of alternatives was carried out over 9 months, from 15 May 2019 to 15 February 2020. Economic, environmental, and social variables were calculated

The data of the semi-intensive system for the diagnosis of the current operation was collected during the research stay, with the information provided by the chief executive officer (CEO) through reports, procedures implemented for the control of production, and quality of water and finance. In addition, direct observation and open interviews were carried out with the production staff of the aquaculture farm, supporting them in determining the current operating conditions of the aquaculture farm with the SIS system

Finally, economic, environmental and social variables were calculated for the SIS * system in operation and the proposed systems: biofloc technology system (BFT), recirculation system in aquaculture (RAS), aquaponics system, and integrated recirculation system with constructed wetland.

\subsection{Proposal with Biofloc Technology System (BFT)}

This system is proposed to be implemented in module II, where the results are calculated and estimated following the methodology proposed by Avnimelech [59] and Celdrán-Sabater [23]. Since the implementation of the BFT is possible with the current infrastructure, the only important difference compared with the SIS is the aeration capacity, which needs to be increased. With the addition of 2 HP (160 CFM) regenerative sweetwater blowers, using 36 diffuser discs or FlexAir ${ }^{\circledR}$ bubble discs for diffusion, with which the system is integrated with an aeration capacity of $15 \mathrm{Hp}$ with 480 CFM, its independent operation is proposed, although connected to the same air network, since the oxygen demand is not the same during the production cycle.

The system has a sedimentation unit per pond. In the design of this system, it is recommended to incorporate a reservoir with a storage capacity of $900 \mathrm{~m}^{3}$, with the objective of storing the water with bioflocs, so that when the crops are harvested, these waters are not discharged and can be reused for the subsequent production period or for agricultural irrigation. This saves time in the preparation of the ponds for the generation of the flocs. This additional investment is congruent with the purpose of the technology, which seeks zero replacement. Occupying an additional land area of $1200 \mathrm{~m}^{2}$ as shown in Figure 3.

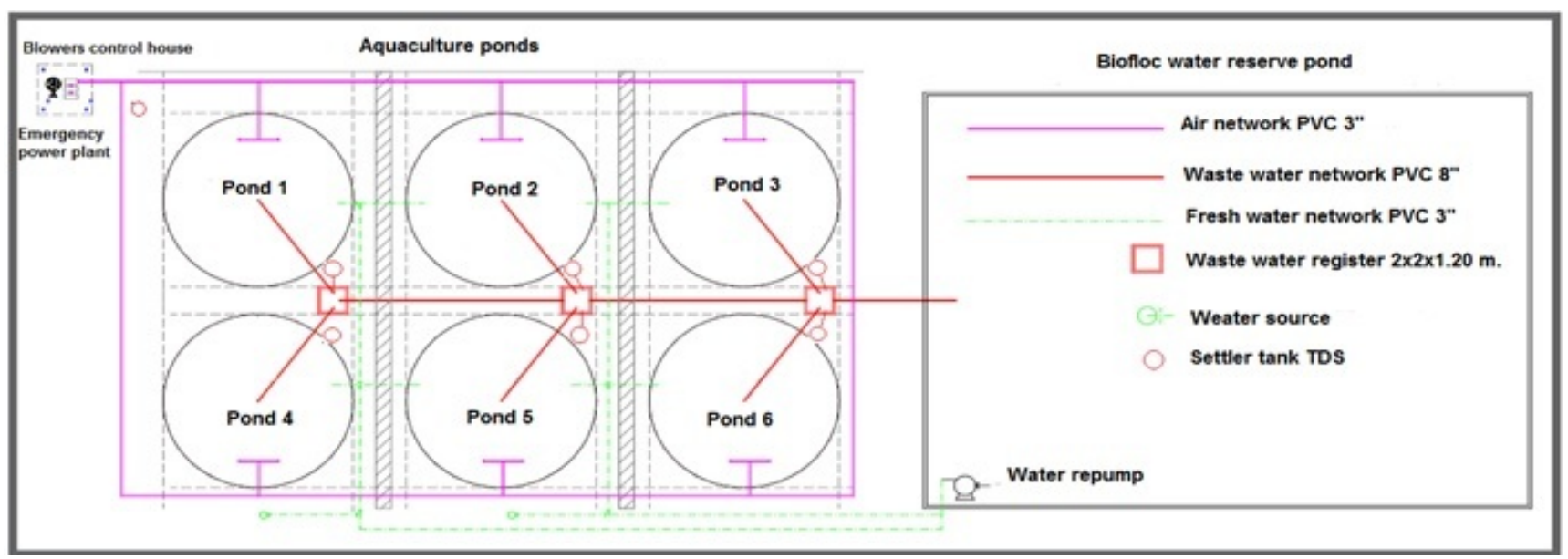

Figure 3. Pond design scheme with biofloc technology. 


\subsection{Proposal for a Recirculation System in Aquaculture (RAS)}

This system is also theoretical. It is proposed to implement its calculation in module II, which was estimated following the design methodology proposed by Ingle de la Mora [60], Timmons et al. [24], and Piedrahhita and Delong [61]. The system consists of the same six circular ponds, which are connected to: a settler, a stabilization pond, submerged biofilters, a rapid sand filter, pumps, a water reconditioning and aeration pond, and an ultraviolet light lamp unit as shown in Figure 4.

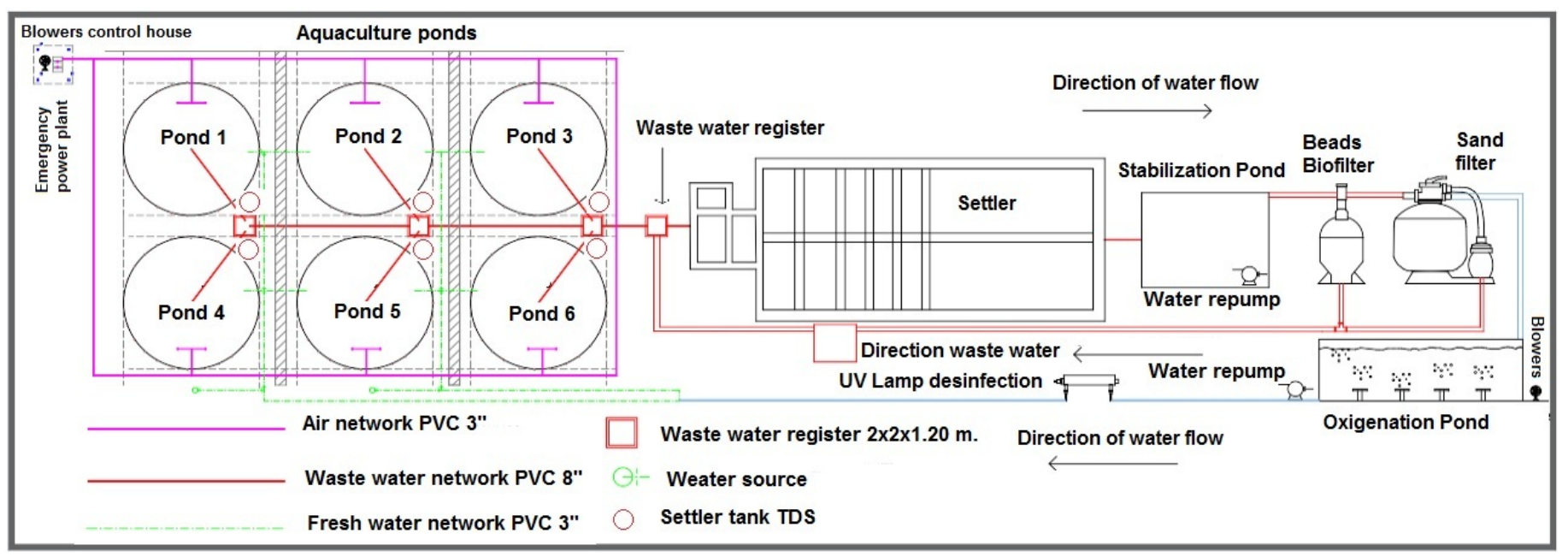

Figure 4. Schematic of the proposed RAS system design, without scale.

The water flow through the entire system is approximately $427.8 \mathrm{~m}^{3}$ per day. Each circular pond has an operating volume of $814 \mathrm{~m}^{3}$ and an average water flow of $76.3 \mathrm{~m}^{3}$ per hour, producing a total turnover of 5.4 times per day. The water passes through the other components of the system, pumping an average of $23 \mathrm{~h}$ per day. The culture ponds and biofilters are permanently supplied with 1440 CFM, by means of a blower arrangement with 45 horsepower, which supplies aeration to the entire system. The settler capacity is $200 \mathrm{~m}^{3}$ and the biofilters are $60 \mathrm{~m}^{3}$ and operate with biospheres.

\subsection{Aquaponics System Proposal (AS)}

Considering a recirculation system, it is feasible to incorporate a hydroponic system (Figure 5). This system was calculated to propose an extra income for agricultural producers, to be implemented in the same way in module II, where the results are calculated and estimated following the design methodology proposed by Rakocy et al. [62] and Goddek et al. [27].

It is proposed to integrate this RAS production system with hydroponic components, for an area of $5000 \mathrm{~m}^{2}$ under tunnel-type greenhouse conditions with zenithal windows. The supports are made of galvanized iron pipes and have an interior separation of $5 \times 8$. The height is proposed to be $5 \mathrm{~m}$ for adequate ventilation; in the lateral bands the proposal is $4 \mathrm{~m}$. The width of these bays will be $9 \mathrm{~m}$ and will allow several bays to be attached in battery. Ventilation is provided by zenithal windows that open to the outside of the greenhouse where a hydroponic irrigation system is proposed to produce habanero peppers (Capsicum chinense). This system consists of the installation of 4" diameter PVC pipes as the central network coming from the RAS biofilter and connected to 2" lateral lines connected to drip lines with a hose to each bag measuring $25 \mathrm{~cm}$ diameter $\times 30 \mathrm{~cm}$ high, filled with tezontle substrate that is characterized by a $\mathrm{pH}$ close to neutral. It is also proposed that the particle size is in a range between 10 to $20 \mathrm{~mm}$. 


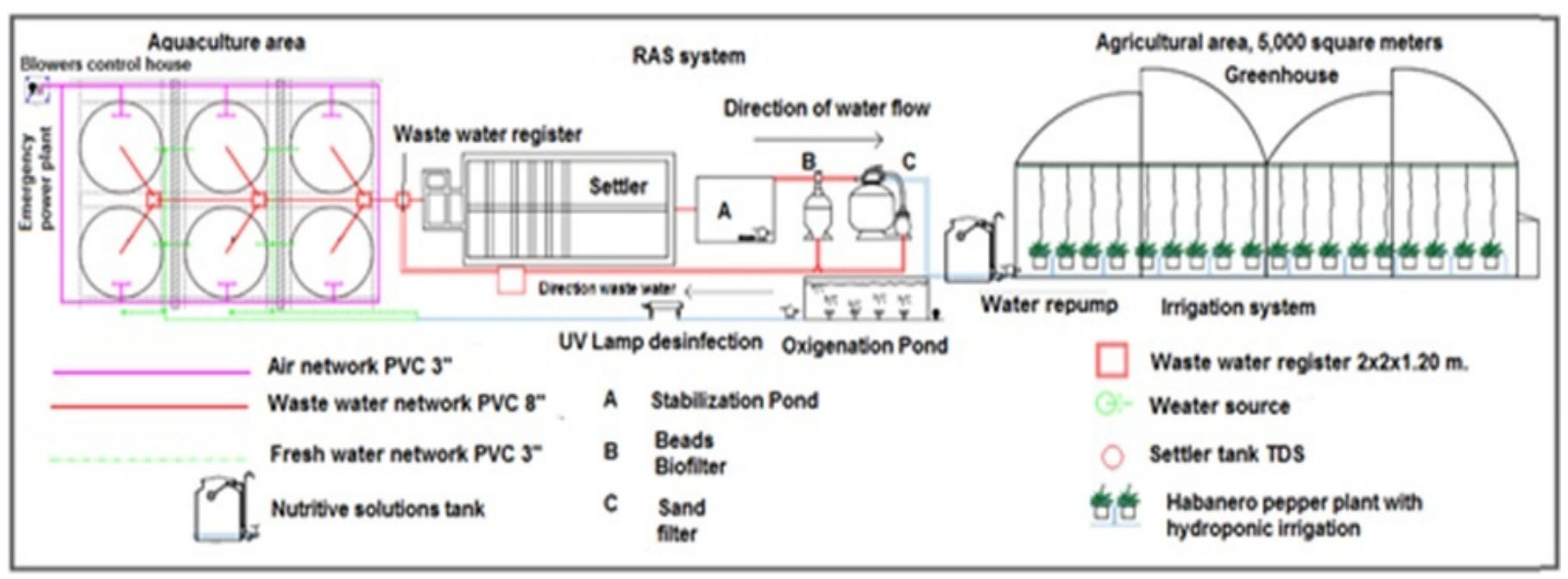

Figure 5. Schematic of the design of the integrated agri-aquaculture system (IAAS).

In this system, the nutrient solution is provided by the water from the RAS. The proposed area is expected to have 10,000 projected plants. In the case of habanero peppers, it was demonstrated that nitrogen is the essential element with the highest demand and that it is always present in higher proportions in plant tissues with respect to the other elements, in the different phenological stages [63], making it suitable for cultivation in the study region [64]. Irrigation water will be collected for reintegration into the aquaculture system.

\subsection{Proposed Integrated Recirculation System with Constructed Wetland (RAS-CW)}

Finally, the construction of a treatment system using this method was calculated and analyzed, although with the capacity to reincorporate the treated water into the system and not only to lower the organic load of the discharges. This system is also intended to be implemented in module II. The wetland was designed following the standards proposed by Lara-Borrero [65] and Rivas-Hernández [66]. The installation requires: an aquaculture unit, a sedimenter, a constructed wetland, and a reservoir (Figure 6).

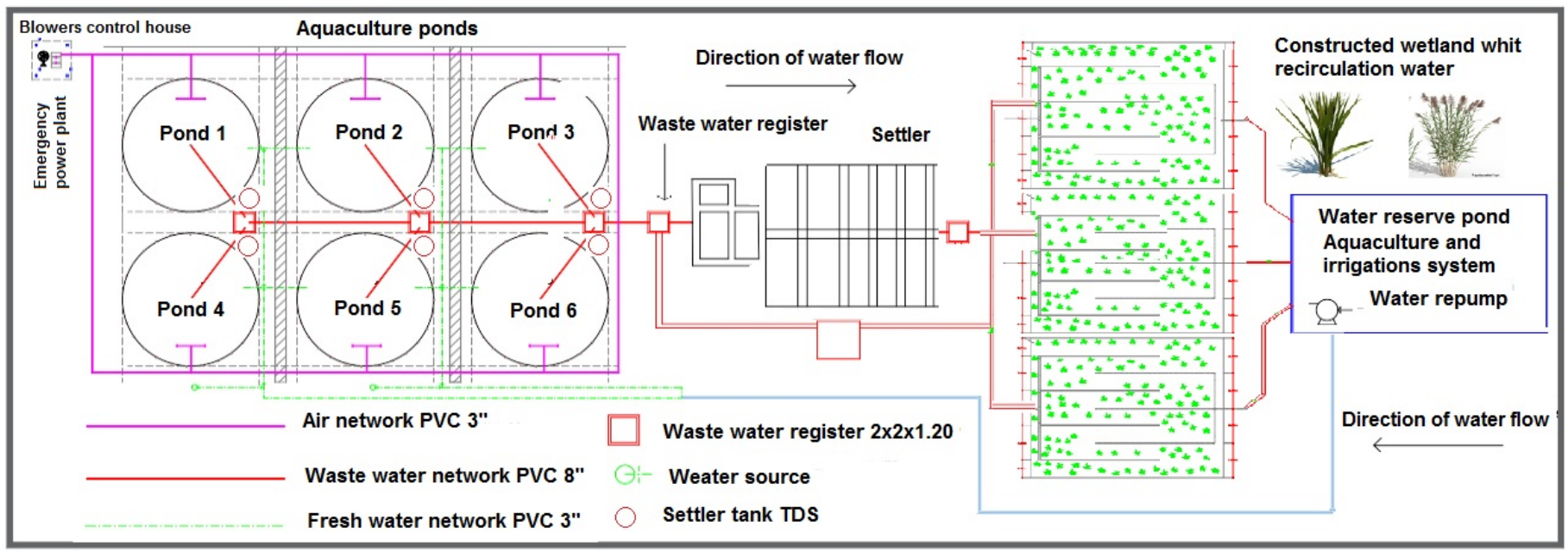

Figure 6. Schematic of closed system of an aquaculture facility with constructed wetland for water treatment, without scale.

It was determined that a vertically operated subsuperficial subsurface flow constructed wetland system is appropriate, consisting of three cells, each of $900 \mathrm{~m}^{2}$ with a 1:1 ratio that together have the capacity to treat $1036 \mathrm{~m}^{3}$, with a hydraulic retention time of $72 \mathrm{~h}$ per cell. Therefore, it has the capacity to treat $3108 \mathrm{~m}^{3}$. 
It was decided to use reeds (Phragmites australis) together with tule (Typha sp.) at a density of 10 plants $/ \mathrm{m}^{2}$. Said species were selected for their easy adaptation in any type of climate and high pollutant removal rates $[48,51,67,68]$. The substrate to be used will be tezontle as an anchoring medium for the plants, which have a $\mathrm{TN}(\mathrm{mg} / \mathrm{L})$ removal capacity of $57 \%, \mathrm{NO}_{2}-\mathrm{N}(\mathrm{mg} / \mathrm{L}) 90 \%$, and $\mathrm{NO}_{3}-\mathrm{N}(\mathrm{mg} / \mathrm{L}) 68 \%$ [26].

\subsection{Economic Environmental and Social Evaluation}

The calculations of the economic variables for the financial evaluation were performed according to the methodology proposed by Blank and Tarquin [69] and Baca [70] for evaluating investment projects. The social and environmental variables selected for analysis were taken according to the proposals of Sarandón et al. [71] to evaluate sustainability, as well as the system of green production indicators (SGPI) by Cervera-Ferri and Luz Oreña [72], adapted for aquaculture production.

To select an appropriate variable to evaluate sustainability in aquaculture, it must be recognized by technical, scientific, representative, relevant, and quantifiable criteria. In this way, the dimensions and their variables must be able to show progress towards the sustainability of aquaculture systems. Based on these criteria, Table 1 presents the three dimensions of sustainability and their variables used for aquaculture systems, considering 13 economic, 10 environmental, and 5 social. Which were considered appropriate to address the study.

Table 1. Economic environmental and social dimensions and variables and units.

\begin{tabular}{ccc}
\hline Economic & Environmental & Social \\
\hline Construction cost (USD) & Volume of pond water $\left(\mathrm{m}^{3}\right)$ & Workdays generated cycle \\
Income from tilapia production (USD) & Daily water replacement $(\%)$ & Stability and reliability \\
Income from agricultural production (USD) & Daily water discharge $\left(\mathrm{m}^{3}\right)$ & Access to and use of technology \\
Tilapia in the system (organisms) & Aeration energy required $(\mathrm{HP})$ & Commercialization of production \\
Planting density (Organisms $\left./ \mathrm{m}^{3}\right)$ & Aeration energy $(\mathrm{kW} /$ hour $/$ day) & \\
System productivity $\left(\mathrm{kg} / \mathrm{m}^{3}\right)$ & Energy required $(\mathrm{kW} /$ hour $/$ day) & $\mathrm{kW} /$ hour $/$ day total \\
Fish production $(\mathrm{kg})$ & $\mathrm{CO}_{2}$ emissions per energy $(\mathrm{kg})$ & \\
Agricultural output $(\mathrm{kg})$ & Land area required $\left(\mathrm{m}^{2}\right)$ & \\
Feed supplied $(\mathrm{kg})$ & & \\
Feed conversion factor $(\mathrm{kg})$ & Kilos of food produced per area unit $\left(\mathrm{kg} / \mathrm{m}^{2}\right)$ & \\
Net present value $(\mathrm{USD})$ & & \\
Internal rate of return $(\%)$ & & \\
Benefit-cost ratio & & \\
\hline
\end{tabular}

\section{Results and Discussion}

It is important to observe the results of the estimations of the exposed systems from social, environmental, and economic dimensions. Despite the fact that the literature presumes these systems to be sustainable in their operation, this analysis, which contemplates the three variables, allows obtaining a broad view of them. It is not intended to determine which of them is sustainable, among other reasons because of the difficulty of translating the philosophical and ideological aspects of sustainability into the ability to make decisions in this regard [71]. This analysis establishes the elements to deepen the study of the application of these ecotechnologies, taking into consideration the assumptions exposed, and the decision making in the management of the study site.

As proposed, Sarandón et al. [71] established that the productive unit must comply satisfactorily and simultaneously with the following requirements: to be sufficiently productive, economically viable, and environmentally adequate. In our case study, these dimensions are taken into account in order to apply them to aquaculture. 


\subsection{Economic Dimension}

Table 2 shows the results obtained in the economic dimension for the aquaculture systems analyzed.

Table 2. Results of the aquaculture systems analyzed by production cycle. Economic and productivity variables.

\begin{tabular}{|c|c|c|c|c|c|}
\hline \multirow[t]{2}{*}{ Variable } & \multicolumn{5}{|c|}{ System } \\
\hline & SIS & BFT & RAS & $\mathrm{CW}$ & AS \\
\hline Construction cost (USD) & $44,807.78$ & $54,805.96$ & $80,382.07$ & $109,611.92$ & $132,578.22$ \\
\hline Income from tilapia production (USD) & $16,570.19$ & $38,238.90$ & $127,463.00$ & $16,571.23$ & $50,985.20$ \\
\hline Income from agricultural production (USD) & - & - & - & - & $182,686.53$ \\
\hline Tilapia in the system (organisms) & 10,582 & 24,420 & 81,400 & 10,582 & 16,280 \\
\hline Planting density (Organisms $/ \mathrm{m}^{3}$ ) & 13 & 30 & 100 & 13 & 20 \\
\hline System productivity $\left(\mathrm{kg} / \mathrm{m}^{3}\right)$ & 6.5 & 15 & 50 & 6.5 & 10 \\
\hline Fish production $(\mathrm{kg})$ & 5291 & 12,210 & 40,700 & 5291 & 8140 \\
\hline Agricultural output (kg) & - & - & - & - & 70,000 \\
\hline Feed supplied (kg) & 7936 & 13,441 & 61,050 & 7936 & 12,210 \\
\hline Feed conversion factor $(\mathrm{kg})$ & 1.5 & 1.1 & 1.5 & 1.5 & 1.5 \\
\hline Net present value (USD) & $19,994.51$ & $169,109.11$ & $479,837.25$ & $20,398.51$ & $1,098,536.41$ \\
\hline Internal rate of return $(\%)$ & 23.7 & 38.32 & 40.65 & 16.51 & 39.51 \\
\hline Benefit-cost ratio & 1.17 & 2.10 & 1.81 & 1.17 & 2.60 \\
\hline
\end{tabular}

SIS: semi-intensive system; BFT: biofloc technology systems; RAS: recirculating aquaculture systems; CW: constructed wetland system; AS: aquaponic system. (B) energy for water pumping; (R) energy for water recirculation.

\subsubsection{Construction Costs}

The five systems have different costs, so their application will depend to a great extent on economic availability for their construction. It is evident that with the increase in technification to closed systems, cost increases. This aspect provides evidence of why such systems are little used in Mexico: high initial construction cost compared with a semiintensive system (SIS). This aspect is also reported by Trejo-lgueravide [73] in aquaculture crops in Tamaulipas, Mexico, but for the case of extensive systems.

In relation to the AS, from an economic point of view, the hydroponic system requires the highest implementation cost because it is a combination between aquaculture and agriculture, requiring the construction of greenhouses for tropical climate of medium technology.

\subsubsection{Income from Tilapia and Agricultural Production}

The SIS and the CW systems generated the lowest income, mainly due to the low system load compared with the BFT, RAS, and AS systems, which due to their characteristics operate with a greater number of organisms. The RAS system stands out for its high production potential.

Exchange rate 19.1 MXN per USD as of 28 February 2020.

In relation to the AS and having agricultural production as the main source of income, the high income from the sale of agricultural production stands out. Since the habanero pepper (Capsicum chinense), an agricultural product with high commercial value was selected, this system demonstrates an advantage over the other systems analyzed, showing the possibility to produce up to 70 tons of product.

\subsubsection{Tilapia in the System and Fish Production}

Each system operates with different amounts of fish, although the SIS and CW operate with the same amount, because the objective of the $\mathrm{CW}$ is to treat wastewater and not to increase production. In the BFT system it is possible to increase production up to 2.3 times. The increase in production is notorious in the RAS, since it is possible to increase it up to 7.6 times. The AS is more productive (1.5 times) than the SIS, although production is not its main objective. 


\subsubsection{Seeding Density and Productivity}

These variables are related to the previous one and take into consideration the area of the culture ponds analyzed, which in all are considered to consist of $814 \mathrm{~m}^{3}$ of water volume. Similar to the RAS and BFT systems, productivity and seeding density were higher compared with the SIS, CW, and AS. Therefore, it is possible to consider these systems as having the highest productivity per unit volume.

\subsubsection{Feed Supplied and Feed Conversion Factor}

This is a determining factor in production costs and in this sense, in the systems analyzed, the greater the number of organisms to be cultivated, the greater the amount of feed necessary to reach a commercial size. The BFT is the system that stands out in this aspect. This is due to its ability to generate natural feed in situ, and this can be reduced up to $25 \%$ [74], which allows this variable to stand out compared with the other systems, which are highly dependent on balanced feed.

\subsubsection{Net Present Value, Internal Rate of Return, and Benefit-Cost Ratio}

These economic variables are generally accepted for the evaluation of investment projects. A five year evaluation period was considered, where the results confirm the economic viability of the proposed designs. The criteria for accepting or rejecting investment projects are as follows: the net present value should be positive, the internal rate of return (IRR) should be better than that offered by the treasury certificates (CETES) for the Mexican case, and the benefit/cost ratio should always be greater than unity. When these three sustainable indicators are met, it is possible to consider the projects as viable $[69,75]$

Considering the above criteria and leaving for a moment the AS, which offers the advantage of agricultural production, the BFT system obtained a positive and high present value, with a rate of return of $38 \%$ and a benefit-cost ratio of 2.10 , which indicates that every dollar invested is recovered and a profit of 1.1 is also obtained. Therefore, the BFT aquaculture system achieves the best results, since it requires less investment and offers a high benefit-cost ratio.

On the other hand, it is evident that the RAS also yielded favorable results economically; aspects already reported by Badiola et al. [76]. Although it has the disadvantage of having the highest investment and operating costs, which is a limitation to its implementation.

As for the SIS, even with acceptable profitability, it is undoubtedly fragile, due to the high operating costs for pumping and aeration, coupled with its low productivity compared with the other systems.

The CW system has an important environmental advantage, but in economic terms its possible implementation is affected by the low productivity of the aquaculture system. However, despite this, the results of the evaluation affirm that its construction is economically feasible for application in aquaculture production and above all, in places where there is little availability of water, since it offers treatment with a very low operating cost. Its limitation is that it requires space and an initial investment much higher than the SSI, BFT, and RAS, but if the land is available there would be no disadvantage.

Finally, it is noted that AS is an outstanding system for aquaculture production, but even more so for agriculture. We can reaffirm that the principle of AS is to recycle nutrients for plants to take advantage of. In this case, it is observed that it is the system with the highest initial and operating costs, but its high impact on economic viability lies in the high agricultural production and price of the selected product, leaving pure aquaculture systems at a disadvantage. It is important to mention that aquaculture is considered a high-risk investment [24] due to its operational characteristics, so this analysis and the variables studied provide a broad view of the economic advantages that can encourage its application. This aspect was also analyzed by Rodríguez-González [77], who determined that aquaponic systems are an alternative for tilapia farming, however, it is essential to control nutrients in the system and to evaluate it economically. 


\subsection{Environmental Dimension}

The ecological aspects of the systems are mainly observed, where land, water and energy use stand out (Table 3).

Table 3. Calculated results of the aquaculture systems analyzed by production cycle. Environmental variables.

\begin{tabular}{cccccc}
\hline Variable & \multicolumn{5}{c}{ System } \\
\hline & SIS & BFT & RAS & CW & AS \\
\hline Volume of pond water $\left(\mathrm{m}^{3}\right)$ & 814 & 814 & 814 & 814 & 814 \\
Daily water replacement $(\%)$ & 30 & 2 & 5 & 5 & 10 \\
Daily water discharge $\left(\mathrm{m}^{3}\right)$ & 244.2 & 8.14 & 40.7 & 40.7 & 81.40 \\
Aeration energy required (HP) & 5 & 15 & 45 & 7.5 & 20 \\
Aeration energy (kW/hour/day) & 44.47 & 268.2 & 804.6 & 67.05 & 357.6 \\
Energy required (kW/hour/day) & $119.3(\mathrm{~B})$ & $4.96(\mathrm{~B})$ & $19.86(\mathrm{~B})$ & $19.86(\mathrm{~B})$ & $39.72(\mathrm{~B})$ \\
kW/hour/day total & 354.98 & 273.16 & 995.81 & 131.61 & 442.02 \\
$\mathrm{CO}_{2}$ emissions per energy. $(\mathrm{kg})$ & 136.66 & 105.16 & 383.36 & 50.66 & 170.17 \\
Land area required (m $\left.{ }^{2}\right)$ & 600 & 1500 & 900 & 3300 & 5900 \\
$\mathrm{Kilos}_{\text {of food produced per area }}$ & 8.81 & 8.14 & 45.22 & 1.6 & 13.24 \\
unit (kg/m ${ }^{2}$ ) & & & & & $44.7(\mathrm{R})$ \\
\hline
\end{tabular}

SIS: Semi-intensive system; BFT: biofloc technology systems; RAS: recirculating aquaculture systems; CW: constructed wetland system; AS: aquaponic system. (B) energy for water pumping; (R) energy for water recirculation.

\subsubsection{Pond Water Volume}

This analysis considers the same volume of the ponds on the farm, i.e., $814 \mathrm{~m}^{3}$, a volume of $135 \mathrm{~m}^{3}$ for each pond of $12 \mathrm{~m}$ in diameter. This is the size available in the current semi-intensive system.

\subsubsection{Daily Water Replacement and Discharge}

In this variable each system operates with different daily replacement rates to maintain optimal water quality for fish production. This is a vitally important aspect in aquaculture and depends on many aspects.

The SIS stands out for its high daily turnover, which reached up to $30 \%$, with 13 organisms $/ \mathrm{m}^{3}$ of planting density. Reduced water use is one of the factors that led to promotion of the present research.

The proposed alternatives require less replacement (Table 2). The BFT with its implementation is advantageous from this point of view, compared with RAS, CW, and AS. Based on the proposed design, as a whole these systems are considered closed aquaculture systems by minimizing their turnover rate. If we infer the amount of water discharged annually, we would find a stratospheric amount in this aspect, since a SIS farm of this type operates 365 days a year. The replacement in BFT, RAS, and AS is due to the fact that water must be replaced by evaporation and the minimum discharge of total suspended solids, and in cases of emergency.

\subsubsection{Energy for Aeration, Pumping and Recirculation}

This aspect is directly proportional to the culture density. The higher the production, the more the aeration system plays a fundamental role, and in these cases, the differences are evident.

The most efficient system in the use of energy is the $\mathrm{CW}$, due to the low production of fish and the proposed recirculation for its reincorporation into the aquaculture system, which requires pumping to recirculate the water treated by anaerobic biological means. Although the BFT requires more energy for aeration [74], due to the requirements of the system (mixing and aeration of the water), there is a notable saving in the energy required for pumping fresh water, which is significant depending on the characteristics of the 
location of the deep well and the dynamic levels of operation of the pump installed for this purpose.

In the case of the RAS system, since it has the highest production and requires constant aeration $24 \mathrm{~h}$ a day, in addition to pumping for recirculation, it requires the greatest amount of energy for its operation. Even though it is considered the most sustainable method for fish production [76], its high energy consumption can be considered a determining factor in its fixed costs and its sustainability can be questioned. In this sense, energy is an aspect that can be improved with the use of grid-connected photovoltaic systems (G-CPVS), although the initial investment cost would increase due to the acquisition of the photovoltaic system.

\subsection{4. $\mathrm{CO}_{2}$ Emissions from the Use of Electricity}

This aspect has been little studied in the literature, especially in countries such as Mexico, where energy use depends on generating plants that operate from non-renewable sources, so the use of electricity has to be considered. Therefore, depending on the amount of energy used by these systems, it is possible to calculate the $\mathrm{CO}_{2}$ emissions to the atmosphere.

The $\mathrm{CW}$ showed lower emissions because it is a system that does not require energy to treat the water, only to reuse it, followed by the BFT, despite the high aeration required for its operation, in this case at a productivity of 15 organisms $/ \mathrm{m}^{3}$ which was considered appropriate for its initial implementation, although it is possible to increase it with experience in the management of the system. It is observed that, due to the high aeration, the RAS is the system that generates the highest emissions, for this reason this system, although it recycles water, is at a disadvantage from the energy point of view compared with the other systems.

\subsubsection{Land Area Required}

This aspect is important to take into consideration, because the area of arable land is expected to decrease in the future. In the study site there is no land area limitation, therefore the land requirement for $\mathrm{CW}$ and AS stands out. In the case of the $\mathrm{CW}$, it stands out because of the space for the installation of the treatment cells and settling tanks. AS stands out because of the installation of agricultural land. With regard to BFT, it should be clarified that the installation of the reservoir required more space, although it is possible to avoid this and thus operate with the same $600 \mathrm{~m}^{2}$ as the SIS. The RAS system requires additional space for the preparation of its subsystems.

\subsubsection{Kilograms Produced Per Area Unit of Land Required}

When submitting the food production in relation to the space required, it was possible to obtain a variable that indicated that although the AS is the one that produces the greatest number of kilograms of food, it was not the highest result.

As was the case with the RAS with $45.22 \mathrm{~kg} / \mathrm{m}^{2}$, followed by the AS and the BFT. The SIS lagged behind the $\mathrm{CW}$ due to its inability to produce added value to its removal mechanisms, a performance aspect that is necessary to improve, as addressed by MarínMuñiz [51] and Sandoval-Herazo et al. [78], for the production of ornamental plants.

\subsection{Social Dimension}

Finally, the social implications of the application of aquaculture systems are observed, an aspect little considered in the literature (Table 4). 
Table 4. Calculated results of the aquaculture systems analyzed by production cycle. Social variables.

\begin{tabular}{|c|c|c|c|c|c|}
\hline \multirow[t]{2}{*}{ Variable } & \multicolumn{5}{|c|}{ System } \\
\hline & SIS & BFT & RAS & CW & AS \\
\hline Workdays generated cycle & 180 & 540 & 540 & 180 & 900 \\
\hline Education level & low & medium & high & low & high \\
\hline Stability and reliability & high & medium & medium & high & medium \\
\hline Access to and use of technology & easy & difficult & very difficult & easy & very difficult \\
\hline Commercialization of production & immediate & immediate & complex & immediate & complex \\
\hline
\end{tabular}

\subsubsection{Shifts Produced}

When including an agricultural component, the personnel requirement for the AS represents the greatest impact, followed by the BFT and RAS, as it requires three work shifts to maintain surveillance of the critical variables of the system operation and to have prevention protocols in place in case of failures and critical changes in water quality, which put production at risk.

\subsubsection{Education Level}

Timmons et al. [24] state that aquaculture is not for everyone, and that a certain level of education is required, which is a factor that becomes even more important when using complex systems such as the ones analyzed. In application, a high level of education is required for the RAS due to the different processes involved in the system and for the AS because it integrates an additional component such as protected agriculture. In the case of BFT, a high level of knowledge is required for the operation including controlled reproduction of bacteria and the maintenance of water quality without replacement. These aspects undoubtedly limit their application in aquaculture, and producers should preferably have equipment and personnel trained for this purpose.

The SIS and CW systems do not require a high level of knowledge, since their operation designs have less variables to control and maintain a strict follow-up compared with the other systems.

\subsubsection{Stability and Reliability}

In aquaculture, direct interaction between operators and organisms is very important [79]. In this sense, the SIS and CW are more reliable and stable in their operation. Thus, adverse water quality aspects are easily corrected with replacements, and in the case of power supply failure, with power plants. CWs are susceptible to clogging due to excess organic load, so a settler was incorporated in the design of the RAS, CW, and AS systems, although it is also important to have electrical power backup.

In the case of the RAS, other equipment failures can cause problems, i.e., it has more components that are susceptible to failure: pumps, biofilters, blowers, saturated settlers, and sand filters.

In the case of the BFT, an inadequate carbon-to-nitrogen ratio and low oxygen level in the pond promote an imbalance in water quality that can be fatal to production.

\subsubsection{Access to and Management of Technology}

Closed systems are little applied, mainly due to lack of knowledge and little encouragement for the use of these technologies and their costs.

With regard to the RAS, we agree with Badiola et al. [76] in considering this hightech production system and equipment. As the components of the system increase, the complexity of the operation also increases; therefore, it is simpler to promote the use of aquaculture in SIS. In addition, there are few technical specialists in these systems and little rapprochement between academia and the productive sector.

As for CWs, according to Sandoval-Herazo et al. [78], they still do not contribute significantly to wastewater treatment in Mexico. Another cause of the scarce use of CWs 
in water treatment is the lack of knowledge and the inexistence of accessible designs for potential users $[80,81]$.

\subsubsection{Commercialization of Production}

The greater the quantity of production, the more complex its commercialization becomes. Undoubtedly, implementing a RAS and an AS will first require obtaining a broad portfolio of clients and diverse distribution channels in order to have the capacity to sell the aquaculture and agricultural product at a competitive price. Delaying sales increases the cost of production due to the feed and energy required for the system. In the case of SIS, BFT, and CW, since the production quantity is smaller, the risks in this sense are lower.

\section{Conclusions}

Food production through systems that generate healthy products, economic growth, and social inclusion, and at the same time are produced in an environmentally sustainable manner, is an ideal strategy. According to the systems analyzed in this study, it is evident that they offer different characteristics. When compared, all of them offer an optimal but not definitive solution, which depends on the needs, characteristics of the farm, regulations, and capital.

According to the data obtained, the investment cost of the BFT system in the cultivation of Oreochromis niloticus is lower compared with other ecotechnologies. Therefore, migrating from SIS to BFT becomes easy; additional requirements only increase construction costs by $18 \%$.

On the other hand, from the environmental point of view, the use of BFT stands out in terms of lower water use by $96.7 \%$; in terms of energy, the system with the lowest impact was CW, with $37 \%$ in contrast to SIS.

In the social aspect, the AS stands out, due to its capacity to generate employment in the region; however, the level of education required is higher.

The BFT and RAS are similar due to the personnel requirements to cover $24 \mathrm{~h}$.

The results are important because the benefits of these ecotechnologies were analyzed in depth from an integral point of view. In the economic vision it was found that all systems are economically viable; the pure aquaculture system with the best results was RAS, however, it requires greater investment. In the case of BFT, it had the best cost-benefit ratio and the lowest investment cost, which makes it an important alternative to consider. The AS has an advantage for the agricultural production in that it is very outstanding and competes with the BFT in the IRR (internal rate of return) close to $40 \%$ in the evaluation period considered.

The importance for regional development is that the results of this paper offer a broad vision for aquaculturists who wish to migrate to any of these ecotechnologies, which will depend on their objectives and financial capacity to implement them. The BFT, CW, RAS, and CW systems are economically viable, environmentally acceptable, especially in water management, and socially feasible.

In the case of this study, it is determined that biofloc technology offers an alternative with lower additional costs to improve the problems of the aquaculture farm studied, taking into account its complexity of operation and additional energy requirements.

Finally, the results obtained in the research provide aquaculturists and the scientific community with important data to complement the analysis of these ecotechnologies in aquaculture. It was shown that these can be sustainable in their operation, as long as they consider economic aspects in their evaluations, both environmental and social. The incorporation of study variables used for each dimension in this work provides a sustainability analysis useful for decision-making in future projects regarding design, construction, implementation, and future research in the aquaculture sector; thus aiding in mitigation of the excessive use of water, energy, and animal protein for the formulation of fish diets, in addition to the discharge of wastewater into receiving water bodies without treatment. 
Author Contributions: Conceptualization, calculations and system design, E.A.B.-T., M.d.l.Á.P.-Á., J.L.M.-M., and L.E.G.S.; methodology, E.A.B.-T., C.-I.L.-M. and M.d.l.Á.P.-Á.; validation, E.A.B.-T., L.C.S.H., M.d.1.Á.P.-Á. and C.-I.L.-M.; formal analysis, E.A.B.-T., M.d.1.Á.P.-Á. and J.L.M.-M.; investigation, E.A.B.-T., C.G.S.-C., L.C.S.H., and C.-I.L.-M.; resources, E.A.B.-T., C.G.S.-C., L.C.S.H. and C.-I.L.-M.; data curation, E.A.B.-T., L.C.S.H., C.G.S.-C. and L.E.G.S.; writing-original draft preparation, E.A.B.-T., M.d.I.Á.P.-Á., J.L.M.-M., C.G.S.-C., and L.E.G.S.; writing-review and editing, E.A.B.-T., M.d.1.Á.P.-Á., L.C.S.H. and C.-I.L.-M.; visualization, E.A.B.-T., C.G.S.-C., L.C.S.H. and L.E.G.S.; supervision, E.A.B.-T., M.d.1.Á.P.-Á., L.C.S.H. and C.G.S.-C.; project administration, E.A.B.-T., M.d.l.Á.P.-Á. and J.L.M.-M.; and funding acquisition, E.A.B.-T. and M.d.1.Á.P.-Á. All authors have read and agreed to the published version of the manuscript.

Funding: The study received external funding from the Mexican Consejo Nacional de Ciencia y Tecnología, Programa Nacional de Posgrados de Calidad (CONACYT, National Council for Science and Technology) and an academic postdoctoral stay with the project to develop an emergent plan in the face of the impacts of COVID-19 in SMEs dedicated to the aquaculture of tilapia (O. niloticus) in the state of Veracruz: sustainable production and marketing alternatives in the face of a new economic scenario.

Institutional Review Board Statement: Not applicable.

Informed Consent Statement: Not applicable.

Data Availability Statement: The data supporting the reported results can be requested with the corresponding author lcsandovalh@gmail.com and eabetanzot@itsm.edu.mx.

Conflicts of Interest: The authors declare no conflict of interest.

\section{References}

1. Froehlich, H.E.; Runge, C.A.; Gentry, R.R.; Gaines, S.D.; Halpern, B.S. Comparative terrestrial feed and land use of an aquaculturedominant world. Proc. Natl. Acad. Sci. USA 2018, 115, 5295-5300. [CrossRef]

2. FAO. The State of World Fisheries and Aquaculture. Meeting the Sustainable Goals; FAO: Rome, Italy, 2018; p. 227.

3. Ganguly, S.; Dora, K.C.; Sarkar, S.; Chowdhury, S. Supplementation of prebiotics in fish feed: A review. Rev. Fish Biol. Fish. 2013, 23, 195-199. [CrossRef]

4. FAO. The State of World Fisheries and Aquaculture; FAO: Rome, Italy, 2014; p. 200.

5. Wang, M.; Lu, M. Tilapia polyculture: A global review. Aquac. Res. 2016, 47, 2363-2374. [CrossRef]

6. Moura, R.S.T.; Valenti, W.C.; Henry-Silva, G.G. Sustainability of Nile tilapia net-cage culture in a reservoir in a semi-arid region. Ecol. Indic. 2016, 66, 574-582. [CrossRef]

7. Santos, J.F.; Assis, C.R.D.; Soares, K.L.S.; Rafael, R.E.Q.; Oliveira, V.M.; de Vasconcelos Filho, J.E.; França, R.C.P.; Lemos, D.; Bezerra, R.S. A comparative study on Nile tilapia under different culture systems: Effect on the growth parameters and proposition of new growth models. Aquaculture 2019, 503, 128-138. [CrossRef]

8. SAGARPA. Avanza México Como Una Potencia De Producción Acuícola. Mexico. 2017. Available online: https://www.gob.mx/ agricultura/prensa/avanza-mexico-como-una-potencia-en-produccion-acuicola (accessed on 13 March 2021).

9. CONAPESCA. Situación actual de la acuacultura en México. In Proceedings of the XII Foro Internacional de Acuacultura, Guadalajara Jalisco, Mexico, 27-29 September 2017. Available online: https://fiacui.com/2017/Tilapia/Jueves\%20 28\%20sep/Copia\%20de\%2005\%20Situacio\%CC \%81n\%20actual\%20de\%20la\%20acuicultura \%20en \%20Me\%CC\%81xico \%20 COMISIONADO\%20MARIO\%20AGUILAR\%20SANCHEZ\%20CONAPESCA.pdf (accessed on 13 March 2021).

10. Reyes-Vera, A.M.; Román-Gutiérrez, A.D.; Guzmán-Ortiz, F.A.; Pulido-Flores, G.; Velasco-Amaro, P.I. An Overview of Aquaculture Activity in Hidalgo State. In Water Availability and Management in Mexico; Otazo-Sánchez, E., Navarro-Frómeta, A., Singh, V., Eds.; Springer: Cham, Switzerland, 2020; Volume 88, pp. 267-286.

11. Fitzsimmons, K.M. Tilapia: The most important aquaculture species of the 21st century. In Proceedings of the 5th International Symposium on Tilapia Aquaculture, Rio de Janeiro, Brazil, 3-7 September 2000; pp. 3-8.

12. Guzmán Amaya, P.; Fuentes Castellanos, D.F. Pesca, Acuacultura e Investigación en México, 1st ed.; Centro de Estudios para el Desarrollo Rural Sustentable y la Soberanía Alimentaria: Mexico City, Mexico, 2006; p. 384.

13. Magallon-Barajas, F.J.; Villarreal-Colmenares, H.; Arcos-Ortega, F.; Civera-Ceracedo, R.; Cruz-Hernández, P. Desarrollo Sustentable de la Acuacultura en México; Publicaciones Especiales del Centro de Investigaciones Bilógicas de Noroeste S.C., Cámara de Diputados, LX Legislatura: Mexico City, Mexico, 2007; p. 264.

14. CONAPESCA. Anuario Estadístico de Acuacultura y Pesca Edición 2013, 1st ed.; CONAPESCA: Mexico City, Mexico, $2013 ;$ p. 299.

15. SAGARPA. Situación Actual de la Acuacultura en Tabasco, Problemática y Perspectivas de Desarrollo a Través de la Innovación Tecnológica; SAGARPA: Mexico City, Mexico, 2015; p. 128.

16. Velasco Amaro, P.I.; Calvario Martínez, O.; Pulido Flores, G.; Acevedo Sandoval, O.; Castro Rosas, J.; Román-Gutiérrez, A.D. Problemática Ambiental de la Actividad Piscícola en el Estado de Hidalgo, México. Ingeniería 2012, 16, 165-174. 
17. Ferreira, J.G.; Falconer, L.; Kittiwanich, J.; Ross, L.; Saurel, C.; Wellman, K.; Suvanachai, P. Analysis of production and environmental effects of Nile tilapia and white shrimp culture in Thailand. Aquaculture 2015, 447, 23-36. [CrossRef]

18. FAO. The State of World Fisheries and Aquaculture; FAO: Rome, Italy, 2016; p. 200.

19. Godfray, H.C.; Charles, J.; Crute, I.R.; Haddad, L.; Lawrence, D.; Muir, J.F.; Nisbett, N.; Pretty, J.; Robinson, S.; Toulmin, C.; et al. Introduction: The future of the global food system. Philos. Trans. R. Soc. B. 2010, 365, 2769-2777. [CrossRef]

20. Barrington, K.; Ridler, N.; Chopin, T.; Robinson, S.; Robinson, B. Social aspects of the sustainability of integrated multi-trophic aquaculture. Aquac. Int. 2010, 18, 201-211. [CrossRef]

21. Béné, C.; Arthur, R.; Norbury, H.; Allison, E.H.; Beveridge, M.; Bush, S.; Campling, L.; Leschen, W.; Little, D.; Squires, D.; et al. Contribution of fisheries and aquaculture to food security and poverty reduction: Assessing the current evidence. World Dev. 2016, 79, 177-196. [CrossRef]

22. Avnimelech, Y. Control of microbial activity in aquaculture systems: Active suspension ponds. J. World Aquac. Soc. 2003, 34, 19-21.

23. Celdran-Sabater, D. Curso de Tecnología Biofloc. Veracruz, Mexico. 2018. Available online: Bioacuafloc.com (accessed on 13 March 2021).

24. Timmons, M.B.; Ebeling, J.M.; Piedrahita, R.H. Acuacultura en Sistemas de Recirculación, 1st ed.; Cayuga Aqua Ventures: Freeville, NY, USA, 2009.

25. Lin, Y.F.; Jing, S.R.; Lee, D.Y.; Wang, T.W. Nutrient removal from aquaculture wastewater using a constructed wetlands system. Aquaculture 2002, 209, 169-184. [CrossRef]

26. Lin, Y.F.; Jing, S.R.; Lee, D.Y. The potential use of constructed wetlands in a recirculating aquaculture system for shrimp culture. Environ. Pollut. 2003, 123, 107-113. [CrossRef]

27. Goddek, S.; Joyce, A.; Kotzen, B.; Burnell, G.M. Aquaponics Food Production Systems. Combined Aquaculture and Hydroponic Production Technologies for the Future; Springer: New York, NY, USA, 2019; p. 630.

28. Romano, N. Aquamimicry: A Revolutionary Concept for Shrimp Farming. Glob. Aquac. Advocate 2017. Available online: https:/ / www.aquaculturealliance.org/advocate/aquamimicry-a-revolutionary-concept-for-shrimp-farming/ (accessed on 13 March 2021).

29. Celdran Sabater, D. Bioaquafloc Qué es Aquamimicry? 2018. Available online: https://www.bioaquafloc.com/aquamimicry/ que-es-aquamimicry/ (accessed on 13 March 2021).

30. Subasinghe, R.; Soto, D.; Jia, J. Global aquaculture and its role in sustainable development. Rev. Aquacult. 2009, 1, 2-9. [CrossRef]

31. Hunter, M.C.; Smith, R.G.; Schipanski, M.E.; Atwood, L.W.; Mortensen, D.A. Agriculture in 2050: Recalibrating targets for sustainable intensification. Bioscience 2017, 67, 386-391. [CrossRef]

32. Diana, J.S.; Egna, H.S.; Chopin, T.; Peterson, M.S.; Cao, L.; Pomeroy, R.; Verdegem, M.; Slack, W.T.; Bondad-Reantaso, M.G.; Cabello, F. Responsible aquaculture in 2050: Valuing local conditions and human innovations will be key to success. Bioscience 2013, 63, 255-262. [CrossRef]

33. Campbell, B.M.; Thornton, P.; Zougmoré, R.; van Asten, P.; Lipper, L. Sustainable intensification: What is its role in climate smart agriculture? Curr. Opin. Environ. Sustain. 2014, 8, 39-43. [CrossRef]

34. Edwards, P. Aquaculture environment interactions: Past, present and likely future trends. Aquac. Eng. 2015, 447, 2-14. [CrossRef]

35. Avnimelech, Y. Bio-filters: The need for a new comprehensive approach. Aquac. Eng. 2006, 34, 172-178. [CrossRef]

36. Avnimelech, Y. Feeding with microbial flocs by tilapia in minimal discharge bio-flocs technology ponds. Aquaculture 2007, 264, 140-147. [CrossRef]

37. Avnimelech, Y. Tilapia Production Using Biofloc Technology Saving Water, Waste recycling Improves economics. Glob. Aquac. Adv. 2011. Available online: https://www.bioaquafloc.com/aquamimicry/que-es-aquamimicry/ (accessed on 13 March 2021).

38. Crab, R.; Defoirdt, T.; Bossier, P.; Verstraete, W. Biofloc technology in aquaculture: Beneficial effects and future challenges. Aquaculture 2012, 356, 351-356. [CrossRef]

39. Emerenciano, M.; Gaxiola, G.; Cuzon, G. Biofloc Technology (BFT): A review for aquaculture application and animal food industry. Biomass Now Cultiv. Util. 2013, 301-328.

40. Gallardo-Collí, A.; Pérez-Rostro, C.I.; Hernández-Vergara, M.P. Reuse of water from biofloc technology for intensive culture of Nile tilapia (Oreochromis niloticus): Effects on productive performance, organosomatic indices and body composition. Int. Aquat. Res. 2019, 11, 43-55. [CrossRef]

41. Rakocy, J.E. Ten guidelines for aquaponic systems. Aquaponics J. 2007, 46, 14-17.

42. Rakocy, J.E. Aquaponics: Integrating fish and plant culture. Aquac. Prod. Syst. 2012, 1, 343-386.

43. Yogev, U.; Barnes, A.; Gross, A. Nutrients and energy balance analysis for a conceptual model of a three loops off grid, aquaponics. Water 2016, 8, 589. [CrossRef]

44. Bosma, R.H.; Lacambra, L.; Landstra, Y.; Perini, C.; Poulie, J.; Schwaner, M.J.; Yin, Y. The financial feasibility of producing fish and vegetables through aquaponics. Aquac. Eng. 2017, 78, 146-154. [CrossRef]

45. Romero-Aguilar, M.; Colín-Cruz, A.; Sánchez-Salinas, E.; Ortiz-Hernández, M.L. Wastewater treatment by an artificial wetlands pilot system: Evaluation of the organic charge removal. Rev. Int. Contam. Ambient. 2009, 25, 157-167.

46. Chen, Y.; Bracy, R.; Owings, A. Nitrogen and phosphorous removal by ornamental and wetland plants in a greenhouse recirculation research system. HortScience 2009, 44, 1704-1711. [CrossRef] 
47. Carbo-Bacaicoa, R. Integration of wastewater treatment technique through wetlands with recirculation systems for aquaculture. Revista Aqua TIC 2012, 37, 25-31.

48. Vymazal, J. Emergent plants used in free water surface constructed wetlands: A review. Ecol. Eng. 2013, 61, 582-592. [CrossRef]

49. Alarcón Herrera, M.T.; Zurita Martínez, F.; Lara-Borrero, J.A.; Vidal Sáez, G.C. Humedales de Tratamiento: Alternativa de Saneamiento de Aguas Residuales Aplicable en América Latina; Pontificia Universidad Javeriana: Bogotá, Colombia, 2018.

50. Zhang, S.; Zhou, Q.; Xu, D.; He, F.; Cheng, S.; Liang, W.; Du, C.; Wu, Z. Vertical-flow constructed wetlands applied in a recirculating aquaculture system for channel catfish culture: Effects on water quality and zooplankton. Pol. J. Environ. Stud. 2010, 19, 1063-1070.

51. Marín-Muñiz, J.L. Humedales construidos en México para el tratamiento de aguas residuales, producción de plantas ornamentales y reúso del agua. Agroproductividad 2017, 10, 90-95.

52. Zhang, S.Y.; Li, G.; Wu, H.B.; Liu, X.G.; Yao, Y.H.; Tao, L.H.; Liu, L. An integrated recirculating aquaculture system (RAS) for land-based fish farming: The effects on water quality and fish production. Aquac. Eng. 2011, 45, 93-102. [CrossRef]

53. Liu, X.; Xu, H.; Wang, X.; Wu, Z.; Bao, X. An ecological engineering pond aquaculture recirculating system for effluent purification and water quality control. Clean Soil Air Water 2014, 42, 221-228. [CrossRef]

54. Fleckenstein, L.J.; Tierney, T.W.; Ray, A.J. Comparing biofloc, clear-water, and hybrid recirculating nursery systems (Part II): Tilapia (Oreochromis niloticus) production and water quality dynamics. Aquac. Eng. 2018, 82, 80-85. [CrossRef]

55. Moreno, J.A.O.; Cerutti, O.R.M.; Gutiérrez, A.F.F. La Ecotecnología en México; IMAGIA: Mexico City, México, $2014 ;$ p. 125.

56. SMN. Servicio Meteorológico Nacional, Normales Climatológicas. 2016. Available online: http://smn.cna.gob.mx/es/ informacion-climatologica-ver-estado? estado=ver (accessed on 3 January 2021).

57. FAO-SAGARPA. Diagnóstico del Sector Rural y Pesquero de México; Secretaría de Agricultura y Desarrollo Rural, Pesca y Alimentación-Organización de las Naciones Unidas para la Alimentación y la Agricultura: Mexico City, Mexico, $2014 ;$ p. 86.

58. García, A.; Calvario, O. Manual de Buenas Prácticas de PRoducción Acuícola de Tilapia Para la iNocuidad Alimentaria; Centro de Investigación en Alimentos y Desarrollo (CIAD): Mazatlán, Sinaloa, Mexico, 2008.

59. Avnimelech, Y. Biofloc Technology. A Practical Guide Book, 1st ed.; The World Aquaculture Society: Sorrento, LA, USA, 2009.

60. Ingle de la Mora, G.; Villareal-Delgado, E.L.; Arredondo-Figueroa, J.L.; Ponce-Palafox, J.T.; Barriga-Sosa, I.D.L.A. Evaluación de algunos parámetros de calidad del agua en un sistema cerrado de recirculación para la acuacultura, sometido a diferentes cargas de biomasa de peces. Hidrobiológica 2003, 13, 247-253.

61. Piedrahita, R.H.; de Long, D. Workshops of Recirculation Systems in Aquaculture, 1st ed.; Pentair Acuatic eco-systems Inc.: Apopka, FL, USA, 2017; p. 192.

62. Rakocy, J.; Masser, M.P.; Losordo, T. Recirculating Aquaculture Tank Production Systems: Aquaponics-Integrating Fish and Plant Culture. 2016. Available online: https:/ / shareok.org/bitstream/handle/11244/319795/oksd_srac_454_2016-07.pdf?sequence=1 (accessed on 13 March 2021).

63. Noh-Medina, J.; Borges-Gómez, L.; Soria-Fregoso, M. Composición nutrimental de biomasa y tejidos conductores en chile habanero (Capsicum chinense). Trop. Subtrop. Agroecosyst. 2010, 12, 219-228.

64. Bello, R.R.; Nava-Tablada, M.E.; Landeros-Sánchez, C.; Díaz-Padilla, G. Potencial productivo y limitantes para el cultivo de chile habanero (CapsicumchineseJacq.) en el estado de Veracruz, México. RINDERESU 2016, 1, 1-11.

65. Lara-Borrero, J.A. Diseño de Humedales de Tratamiento. In Humedales de Tratamiento Alternativas de Saneamiento de Aguas Residuales en América Latina; Herrera, A., Ed.; Pontifica Universidad Javeriana: Bogota, Colombia, 2018.

66. Rivas-Hernández, A. Construcción de humedales de flujo sub- superficiales vertical/horizontal. In Humedales de Tratamiento Alternativas de Saneamiento de Aguas Residuales en América Latina; Herrera, A., Ed.; Pontifica Universidad Javeriana: Bogota, Colombia, 2018.

67. Vymazal, J.; Kröpfelová, L. Wastewater Treatment in Constructed Wetlands Horizontal Subsurface Flow; Springer: Dordrecht, The Netherlands, 2008.

68. Vymazal, J.; Kröpfelová, L. Removal of nitrogen in constructed wetlands with horizontal sub-sureface flow: A review. Wetlands 2009, 29, 1114-1124. [CrossRef]

69. Blank, L.; Tarquin, A. Ingeniería Económica, 7th ed.; McGraw Hill: Mexico City, Mexico, 2012; p. 611.

70. Baca, U.G. Evaluación de Proyectos de Inversión; McGraw Hill: Mexico City, Mexico, 2013; p. 363.

71. Sarandón, S.J.; Zuluaga, M.S.; Cieza, R.; Janjetic, L.; Negrete, E. Evaluación de la sustentabilidad de sistemas agrícolas de fincas en Misiones, Argentina, mediante el uso de indicadores. Agroecología 2006, 1, 19-28.

72. Cervera-Ferri, J.L.; Luz Ureña, M. Indicadores de Producción Verde: Una Guía para Avanzar Hacia el Desarrollo Sostenible, 1st ed.; Naciones Unidas-Comisión Económica para América Latina y el Caribe (CEPAL) Vitacura: Santiago, Chile, 2017 ; p. 178.

73. Trejo-lgueravide, R. Evaluación de los cultivos acuícolas en Tamaulipas, México. CienciaUAT 2017, 12, 114-133. [CrossRef]

74. Suárez-Puerto, B.; Delgadillo-Díaz, M.; Sánchez-Solís, M.J.; Gullian-Klanian, M. Analysis of the cost-effectiveness and growth of Nile tilapia (Oreochromis niloticus) in biofloc and green water technologies during two seasons. Aquaculture 2021, 538, 736534. [CrossRef]

75. Canales Salinas, R. Criterios para la toma de decisión de Inversiones. REICE Rev. Electrón. Investig. Cienc. Económ. 2015, 3, 101-117. [CrossRef]

76. Badiola, M.; Mendiola, D.; Bostock, J. Recirculating aquaculture systems (RAS) analysis: Main issues on management and future challenges. Aquac. Eng. 2012, 51, 26-35. [CrossRef] 
77. Rodríguez-González, H.; Rubio-Cabrera, S.G.; García-Ulloa, M.; Montoya-Mejía, M.; Magallón-Barajas, F.J. Análisis técnico de la producción de tilapia (Oreochromis niloticus) y lechuga (Lactuca sativa) en dos sistemas de acuaponía. Agroproductividad 2015, 8, 15-19.

78. Sandoval-Herazo, L.C.; Alvarado-Lassman, A.; Marín-Muñiz, J.L.; Méndez-Contreras, J.M.; Zamora-Castro, S.A. Effects of the Use of Ornamental Plants and Different Substrates in the Removal of Wastewater Pollutants through Microcosms of Constructed Wetlands. Sustainability 2018, 10, 1594. [CrossRef]

79. Acedo, Y.E.F. Acuacultura de Oreochromis Niloticus en SAR y TBF Integrada con Horticultura Hidropónica en Sistemas Sin Recirculación. Ph.D. Thesis, Centro de Investigaciones Biológicas de Noroeste, Mexico City, Mexico, 2019.

80. Pálfy, T.G.; Meyer, D.; Troesch, S.; Gourdon, R.; Olivier, L.; Molle, P. A single-output model for the dynamic design of constructed wetlands treating combined sewer overflow. Environ. Model. Softw. 2018, 102, 49-72. [CrossRef]

81. Avellán, T.; Gremillion, P. Constructed wetlands for resource recovery in developing countries. Renew. Sustain. Energy Rev. 2019, 99, 42-57. [CrossRef] 